A Socio-Spatial Study of School Libraries and Reading

\title{
Reading, School Libraries and Equity: A Socio-Spatial Study of School Libraries and Reading in Singapore
}

Chin Ee, Loh

National Institute of Education, Nanyang Technological University

\begin{abstract}
Although Singapore is lauded internationally for its excellent education system, particularly as a top scorer on the international OECD PISA assessments, official educational policies have been criticized for the tendency to sideline socioeconomic status as a factor for school success. To understand the complex space of schooling and how inequity is worked out in practice, I turn to the space of the school library in two contrasting schools to examine how the organization of space can contribute to or inhibit the kinds of learning desired. Using a comparative socio-spatial approach, I map the library spaces of an elite all-boys' school and a co-educational government school in Singapore to understand how a space typically associated with the cultivation of reading habits and critical information literacy may in practice serve as a space for differentiated education. Through the physical, social and affective mapping of two school libraries, I describe, breakdown and examine taken-forgranted practices that reveal underlying ideologies governing perception and use of library space. Furthermore, I argue that viewing the school library through socio-spatial lens allows educators a localized, evidence-based framework to evaluate how effective and equitable their school libraries are.
\end{abstract}


A Socio-Spatial Study of School Libraries and Reading 
A Socio-Spatial Study of School Libraries and Reading

The importance placed on the school library as a key node in raising the reading and academic achievement of students is well-supported by research documenting the role of school libraries in supporting reading scores and academic achievement (Barratt, 2010; Lance, 2002; Lance \& Hofshire, 2012; Todd \& Kuhlthau, 2005). Extensive reading is correlated to academic achievement (Krashen, 2004), and effective school libraries can do much to support a reading culture (Adkins \& Brendler, 2015; Makatche \& Oberlin, 2011; Wejrowski \& McRae, 2013). Libraries and school libraries can play a key role in supporting educational structures by motivating students to read through the provision of a variety of materials, a supportive environment for literacy and reading conversations, and encouraging student autonomy in making their reading choices (Adkins \& Brendler, 2015).

To understand the complex space of schooling and how inequity is worked out in practice, I turn to the space of the school library in two contrasting schools to examine how the organization of space can contribute to or inhibit the kinds of learning desired. I argue that there is a need to address educational inequity through grounded, localized comparative analyses of reading policies and practices that aim towards genuine social change through “intentional and focused emphasis on the spatial or geographical aspects of justice and injustice" (Soja, 2009, p. 2). Using a comparative socio-spatial approach, I map the library spaces of an elite all-boys' school and a co-educational government school in Singapore to understand how a space typically associated with the cultivation of reading habits and critical 
A Socio-Spatial Study of School Libraries and Reading

information literacy may in practice serve as a space for differentiated education. This paper

further argues that a socio-spatial approach provide a framework for measuring the

effectiveness of the space and programmes of the school library in ensuring educational

effectiveness and equity.

\section{Socio-Spatial Perspectives}

In David Harvey's (2009) Social Justice and they City, he argues that social practices and

processes influence space, which in turn further constraint or enable other social practices

and practices. Space is different from place in not being bounded, container-like, and consists

of not just the material but also imagined spaces (Leander, Phillips, \& Taylor, 2010; Lefebvre,

1991; Soja, 2009) that permeate the actual contained space that is under scrutiny. Spatializing

practice foregrounds how everyday practices are permeated by dominant ideological

discourses, and questions the uncritical acceptance of taken-for-granted and often routine

reading practices present in schools. The reassertion of space in literacy studies is to firstly,

attend to how language practices are distributed socio-geographically and accessed in various

social sites, and secondly, space and literacy practices are socially produced (Mills \& Comber,

2015). In this paper, I argue that viewing learning through socio-spatial perspectives generate

new ways of understanding access and barriers to learning to read within the institutional and 
A Socio-Spatial Study of School Libraries and Reading

physical space of school library as a place typically associated with the cultivation of reading engagement and information literacy skills.

Spatial perspectives require the understanding that schools are not static, bounded containers; instead, they constitute a network of national, institutional and community discourses that evolve over historical time and across space (Nespor, 1997). Although bounded as a place, the space of the school library constitutes the flows and networks within the nation, school and community. Understanding space as an ideologically, interconnected space which can constraint or enable ways of doing-thinking-doing-feeling-being makes visible the multiple, interrelated discourses governing space and its imposition on individuals occupying that space. Lefebvre (1991) explains that through spatial practice, social relations are reproduced or transformed. Spatial arrangements mediate social relations, and the way space is used and organized signifies the importance of particular spaces and the social relations within that space.

Everybody knows what is meant when we speak of a 'room' in an apartment, the 'corner' of the street, a 'marketplace', a shopping or cultural 'centre', a public 'place', and so on. These terms of everyday discourse serve to distinguish, but not to isolate, particular spaces, and in general to describe a social space. They correspond to a specific use of that space, and hence to a spatial practice that they express and constitute. Their interrelations are ordered in a specific way. Might it not be a good idea, therefore, first to make an inventory of them, and then to try and ascertain what paradigm gives them their meaning, what syntax governs their organization? (Lefebvre, 1991, p. 16, italics mine) 
A Socio-Spatial Study of School Libraries and Reading

The spatial practice that Lefebvre speaks of is the everyday quotidian lived experiences of individuals, which are ordered by competing ideologies and discourses permeating the space. By closely observing spatial practice, practicing what de Certeau (1984) termed walking the city - tracking the rhythms and cycles, occupied and empty spaces, use and isolation, habitual movements - allow us to see how social relations are shaped by underlying and competing discourses within each societal space. Thus, individuals bring their home discourses and understandings of reading and learning to their use of school spaces, and school spaces are permeated by community discourses of what it means to read and to learn.

Sociocultural studies of reading illustrate how differentiated upbringing and resources lead to different ways of using words that benefit middle-class children who learn from home practices that confirm to school preferred ways of reading, writing and talking (Heath, 1986; Lareau, 2003; Loh, 2013). Students, thus, come to school with particular predispositions towards reading, established as a factor for school success (Kirsch et al., 2002). For example, in Heath's (1986) seminal study on the home and school literacies of working-class and middle-class children in Piedmont Carolina in the 1970s to 1980s, she illustrated how children from different social classes learn different ways of using words that prepare some better than others for learning in school. For the "Maintown" children from middle-class families, the children learnt how to read in school-accepted ways from their daily interaction with parents through home-literacy practices which could be as innocuous as bedtime reading. 
A Socio-Spatial Study of School Libraries and Reading

On the other hand, students from non-mainstream homes were socialised into different ways of "saying(writing)-doing-being-valuing-believing" (J. P. Gee, 1996, p. 127) that may not aligned to school literacies. These social-classed ways of relating to language at home and school intersect with gender and race (Moss, 2007; Solsken, 1993), and serve as a form of cultural capital that contributes to middle-class students' increased likelihood of academic achievement (Lareau, 2003). Despite the increasing multimodalities and technological advances, "competence in traditional literacies is often a gateway to successful entry into the world of new literacies" (Warshauer, 2007, p. 43). Hence, children who acquire schooled ways of reading are guaranteed access to more knowledge through texts whereas students who have difficulty reading lag behind as they have often find reading too difficult and develop negative attitudes to reading (Kirsch et. al., 2002; Neuman \& Celano, 2012). This "ecology of inequality" (Neuman \& Celano, 2012) is further stratified in the use of public resources, when children's qualitative access to rich literacy experiences is stratified by class. Observing adult and children behaviours at the two equally well-resourced public libraries in Philadelphia, Neuman and Celano noted that adults spent an average of 47 minutes reading to their children in the suburban library, whereas children were left to wander on their own in the urban library. Middle-class children, thus, had the advantage of being socialised into ways of reading or obtaining knowledge through the mentorship of significant others. This study clearly demonstrated that equitable access must include access 
A Socio-Spatial Study of School Libraries and Reading

to knowledgeable others who are able to help students learn how to acquire knowledge in meaningful ways. In another study of four public libraries using a geosemiotic approach, Nichols (2011) demonstrated through the comparison of the libraries how location, design and implicit participations rules may serve to include or exclude poor families from accessing and fully utilising the resources of the library.

Recent educational studies using spatial analysis contribute productively to our understanding of learning from social perspectives, particularly in terms of illuminating our knowledge of the uneven terrain of access to educational opportunities and resources (Jocson \& Thorne-Wallington, 2013; Leander et al., 2010). Drawing chiefly from the work of critical geographers such as Henri Lefebvre (1991), David Harvey (2009) and Edward Soja (2009), these studies argued for a spatialising practice that is aware of the interconnection between space and social relations. Lefebvre (1991) pointed to the importance of understanding the connection between spatial practices and the reproduction or transformation of social relations. Using a triad of spatial practice (lived), representations of space (conceived) and representational spaces (perceived), Lefebvre argued that space can be appropriated for control and domination. Deconstructing the spatial practice of a particular time and place provides insight into the dominant ideologies and narratives that shape how that space is produced and lived, and allow for re-appropriation of space for more equitable distribution of resources and access to these resources. The concept of space and equity is elaborated in 
A Socio-Spatial Study of School Libraries and Reading

Social Justice and the City where Harvey (2009) explained how managing access and

proximity to resources is a way to manage equitable distribution within the population of a

city. By deliberately attending to how equity or inequity is built into the social experiences of

individuals, we gain insight into how to re-imagine and re-organise space for more equitable distribution (Soja, 2009).

Official perceptions of space may differ from students' perceptions and actual use of space. In Schmidt's (2015) study of school space, she demonstrated that the universally regarded "safe" place of school may serve as a place of inclusion and exclusion. For minority youth in her study who were identified as lesbian, gay, bisexual and queer (LGBQ), there were limited safe spaces within school where they could mingle and be seen. In another study on the space of school libraries, Shilling and Cousins (1990) demonstrated how understanding the (mis-)alignment between students' and authorities' perceptions and uses of space can provide insight into why students associate themselves with or disassociate themselves from using the school library. They show how students may use the library in ways unintended by official authorities, and show how official regulation and unofficial colonisation of the social space may exclude certain student population from using the library. A socio-spatial approach attends to how the organization of the physical, social and affective space shapes learning. Through the physical, social and affective mapping of two school libraries, I describe, breakdown and examine taken-for-granted practices that reveal 
A Socio-Spatial Study of School Libraries and Reading

underlying ideologies governing perception and use of library space. Physical mapping refers to the layout and organisation of the school library, and captures the resources and organisation of resources as a starting point to engage in an understanding the use of space in a particular context. Mapping the social (what students do) and affective spaces (what students feel) captures the lived social life on the ground that constitutes our social interaction, affective memories and responses to physical space (Lefebvre, 1991). Detailed observation serves as a way to measure effectiveness of design, curricular and pedagogical transformation in school libraries.

\section{Data Collection and Analysis}

\section{The Educational Context: School Libraries and Learning in Singapore}

Within the Singapore context, the National Library has played a key role in promoting reading, including providing well-stocked public libraries conveniently located in different parts of the island, and working actively to promote reading at schools with the READ@school programme, and with children from low-income families with the kidsREAD programme. However, less attention has been paid to how school libraries (often referred to as School Media Resource Libraries or SMRLs) can be effectively utilized to encourage reading and learning, particularly in secondary school classrooms. Unlike schools in the U.S., Canada or Australia, there is no mandate for Singapore secondary schools to employ teacher- 
A Socio-Spatial Study of School Libraries and Reading

librarians to manage the library. Typically, the job of managing the library is delegated to a subject-teacher, and clerical help in the form of a Library Assistant is employed to manage the day-to-day administrative matters. Often, the amount of attention and resources allocated to the school library depends on the support of the school principal and the culture of each school. Despite various recommendations in the early 2000s to improve Singapore school libraries through measures such as improving the status and required qualifications required for the library supervisor, devoting more time and courses to teacher and librarian training, and providing opportunities for teachers/librarians to collaborate with teachers, community and curriculum planners (M. M. Gee, 1999; Majid, Chaudhry, Foo, \& Logan, 2002; Mokhtar, 2003; Mokhtar \& Majid, 2005; Tan, 2003; Tsai, 2001), little has been achieved in terms of explicit government policy with regard to how school librarians should be managed, and teachers or librarians trained.

Perhaps the efficiency and reach of the National Library, a key player in providing public access to books and knowledge, has led to insufficient attention being paid to school libraries within the Singapore context. Hochman (2016), writing about the school library situation in the U.S. suggests that public perception that school librarians are not vital to the school system may rest in a nostalgic remembrance of the school librarian "as a pleasant person whose work is ultimately irrelevant for contemporary schools" (p. 137). In the same way, views of the school library as an archival of print for silent reading, also act to 
A Socio-Spatial Study of School Libraries and Reading

marginalize the important work of libraries as reading and knowledge hubs. Contemporary school library research point to the importance of the school library for supporting reading (Adkins \& Brendler, 2015; Knapp, 2013), collaboration and research (DelGuidice, 2015), developing critical information literacy skills (Gordon, 2010; Kapitzke \& Bruce, 2006; Todd \& Kuhlthau, 2005), and creating opportunities for doing, whether in the form of Makerspaces (Loertscher, Preddy, \& Derry, 2013) or other activities, to support the development of $21^{\text {st }}$ century literacies and dispositions.

\section{Data Collection and Analysis}

This chapter draws on data from two studies utilizing the case study approach which allows one to "understand complex social phenomenon" (Yin, 2003, p. 2). I adopted a geosemiotic approach sensitive to spatial arrangements and people's social interactions within a space

(Nichols, 2014). The research questions guiding this research study were:

(1) What are the uses of the school libraries in two different schools?

(2) How does the organisation of the space of the school library support the cultivation of desired reading practices within each school?

The first case study was conducted in an elite all-boys school, Ace Independent, from September 2009 to September 2010. The second study was conducted in a co-educational secondary school, Tembusu Secondary School, from September 2013 to September 2014. Key research data for both schools included: visual maps of the library space and time maps 
A Socio-Spatial Study of School Libraries and Reading

of library usage, student interviews and artefacts, interviews with teachers and staff, school

and classroom observations, and surveys.

Each case study was analysed independently and a cross-case comparison was

conducted towards the end of the second study. Attentive to the need for comparison, I

constantly juxtaposed data about the school libraries, and about the students' backgrounds

and practices alongside each other to identify both similarities and differences. Coding the

survey and interview data highlighted the library as a problematic space, and I returned to the interview data to compare students' social uses of and affective responses to their respective

library. I also examined the school context, library spaces and students' responses using the

physical, social and affective framework when that emerged as a significant theme in the

research study. Findings demonstrated qualitative differences not just in library resources, but revealed ideological differences in the design and use of both libraries. For example, while both libraries were utilized for classroom work, the use of one space for completion of essays and the other for inquiry-based work reflected the schools' differentiated literacy practices.

\section{Mapping Library Spaces}

Given that the organisation of school libraries can reveal much about the kinds of practices and habits that are preferred within each milieu and context, and can even reveal tensions between the ideal and practice (Dressman \& Tettegah, 2006), a physical, social and affective 
A Socio-Spatial Study of School Libraries and Reading

mapping of the two libraries provided a way to see the contrasting values accorded to the libraries in both schools, and demonstrates how knowledge is perceived and enacted in the space of the school libraries. Typical measures such as book loans, self-reported surveys, while useful to some degree, may not provide sufficient detail to explain how a library is practically utilized and why it is so.

Both libraries were, on the surface, well-stocked. Ace Independent had quantitatively more books. The Tembusu library stocked 24,000 books (which worked out to about 20 books per student) whereas the Ace library stocked 100,000 books for 1,900 students (52 books per student). Qualitatively, the book collection followed a different logic. The Ace library served both the secondary and IBDP students, and thus included more research resources for the IBDP students. The English department heads in both schools spoke of the importance of the school library and were actively involved in the book selection and renewal process. Tembusu employed a library assistant to help with the day-to-day management of the library whereas Ace Independent employed a librarian. Subject-teachers were responsible for the management of the library and library club for students at both schools.

Both Tembusu and Ace libraries possessed the physical signs of a school library: a librarian's desk, fiction and non-fiction books in shelves, trolleys, magazines and newspapers, some multimedia resource, sofas and armchairs to lounge on, and tables and chairs for students to work. Yet, the Tembusu Media Resource Library gives an impression of being 
A Socio-Spatial Study of School Libraries and Reading

generally empty and under-utilised while the Ace Independent Library seems filled most of the time. Mapping the physical space of a school library was a way to compare what schools had and how they used their resources. The school library, while bounded, is permeated by official and unofficial discourses of what knowledge is, who accesses knowledge and how knowledge is to be used within the school and learning context.

\section{Mapping Physical Spaces}

The organization of the physical space of the library, the materials and resources in the school libraries form the core of this analysis. The focus is on access to space, and the material and social qualities of these spaces to render greater insight into space is used and experienced in relation to students' reading practices and the schools' desired reading aims.

The map of the two school libraries are visual representations of how space is prioritized and organized within the two libraries. 


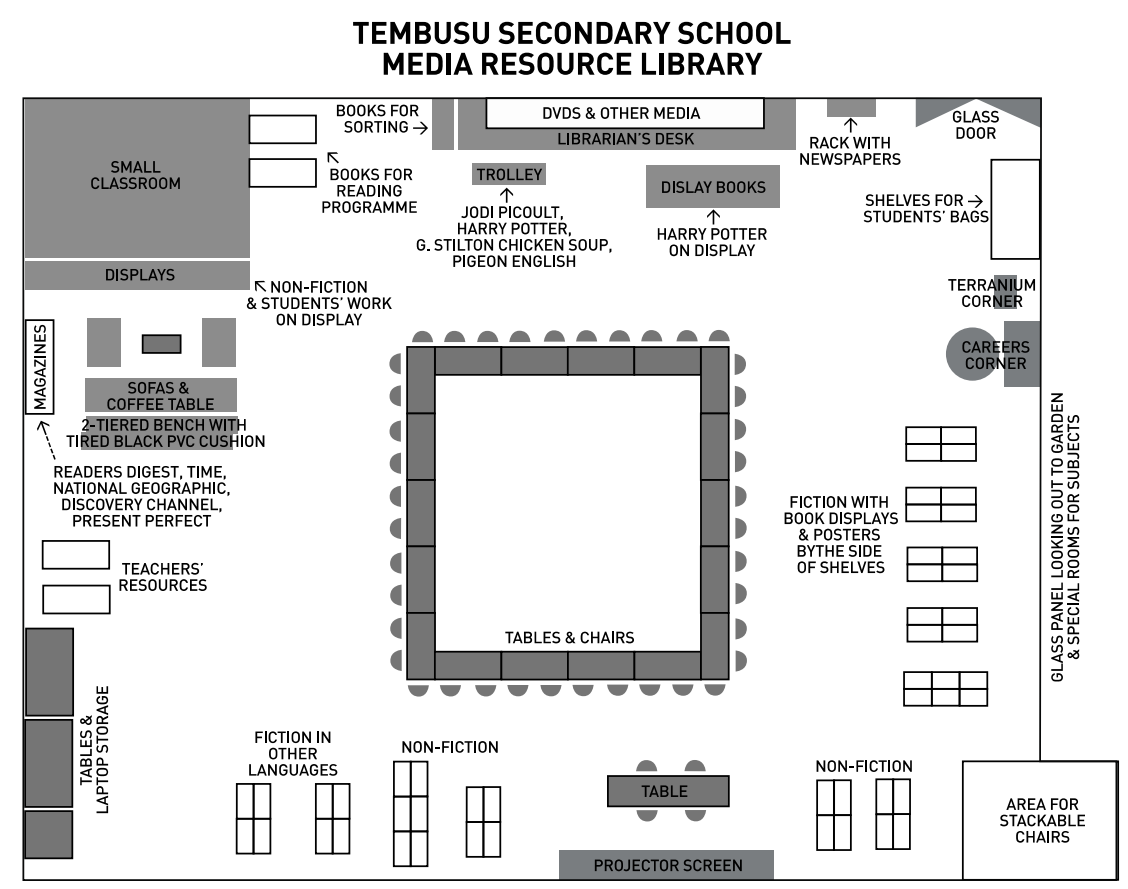

Figure 1. Map of Tembusu Media Resource Library.

Size and Access: The Tembusu Library consists of a single level and is positioned in

an easily accessible location on the first floor of the school. A majority of the students would have to walk by the library on their way to the classroom or from their classroom to the canteen (or cafeteria) for their recess or lunch. Although the location is easily accessible, there was little student traffic. Sometimes, the lights were dimmed to save electricity and it was not clear if the library was opened or not. The library was also often utilized in the afternoons for events such as staff meetings, workshops and to host visitors to the school, which meant that it was not always available for student use. A small classroom that can fit about 20 people can be reserved by teachers but is seldom used. 


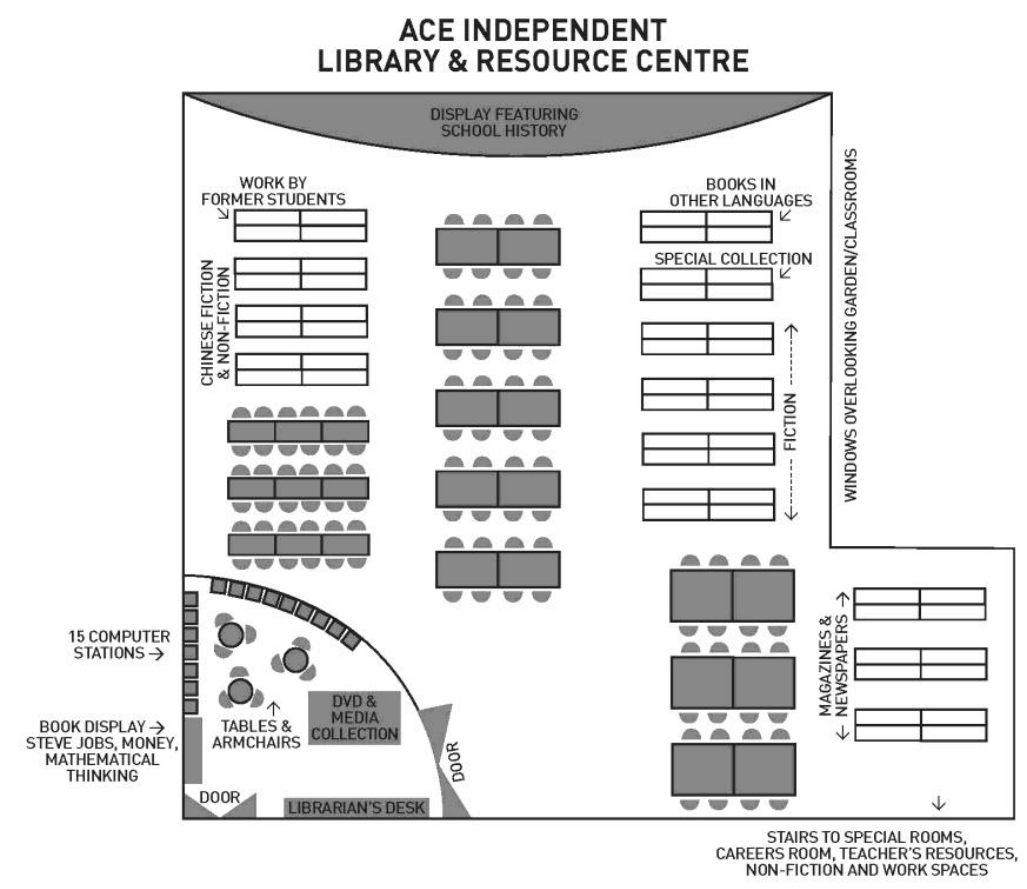

Figure 2. Map of Ace Independent Library, Top Level.

The Ace library is also located at a relatively accessible area of the school, on the

third level of the school. The first level is about thrice the size of Tembusu library and there is a second lower level where most of the non-fiction titles are housed. At the lower level, there is a large Teachers' Resource Room with teaching resources and materials, a room set aside for counseling and two other small rooms for discussion. Like the Tembusu library, the library is sometimes closed for meetings or workshops, but library closure occurs less often as there are other large rooms within the school such as the lecture halls that are more often utilized for meetings. Workshops held in the library tend to be held during the school holidays, when students are less likely to be at school. 
A Socio-Spatial Study of School Libraries and Reading

Display and Decoration: The visual semiotic of place conveys the significance

accorded to particular kinds of literacy events within the space. The representational space is important as it conveys a sense the kinds of reading and learning valued at each school. At Ace Independent, the location of the panels depicting the school's history is located within the library, and the walls of the library are decorated with various themed images or quotes that celebrate reading. For example, images of famous libraries, accompanied by quotes celebrating the libraries decorated the first floor walls. In comparison, the Tembusu library is decorated with generic functional teaching posters (e.g., "Metaphors") or inspirational posters stuck onto the side of the bookshelves. The Ace library is positioned as an archival space (of the school's history and knowledge) as well as a space for discovery about books in comparison to Tembusu's more functional focus.

There is also a notable difference in how books are selected for display. The Ace library book displays, located at shelves next to the library entrance, consists of books curated by trained librarians to privilege current informational texts and some contemporary prize-winning novels. Titles were curated to fit a wide range of interests and the IB focus on global-mindedness and research. In contrast, the book display at Tembusu consists of Young Adult series, curated by the for-profit company managing the library rather than the librarian, and does not take into account the specific profile and programmes of specific schools. One month, I saw a display of Jodi Picoult's titles on the month of her birthday and another month, 
A Socio-Spatial Study of School Libraries and Reading

Geronimo Stilton titles were on display across different schools managed by the same company. Impression given by the books.

Seating, Table and Computer Access: The location of resources and organisation of space shapes the social uses of the space. In Tembusu, students wishing to do online research use computers located near the school office rather than within the library. The laptops stored in the library can only be withdrawn by a teacher for classwork. At Ace, computers are located within the library near the entrance; students can be seen using the computers or seated at the nearby sofas working on their own laptops at any time of the day. The computers at the front of the library near the librarian's desk draw students into the library and adding to the utility value of the library as a useful space for locating information while adding symbolic value to the library as a critical space for the acquisition and application of information literacy (Kapitzke, 2003). In comparison, there was little to draw students into the Tembusu library and students use laptops only either under supervision of teachers when using the laptop, typically typing their essays for submission.

In both schools, there was relatively less reading space compared to study space. In Tembusu, the only sofa set was placed in a corner of the library near the magazine section. In Ace Independent, there were three sets of three armchairs placed near the entrance of the library. Though these spaces were used for reading, they were more often than not used for students' colonized purposes of talking, discussion or doing schoolwork. With regard to 
A Socio-Spatial Study of School Libraries and Reading

study space, the table arrangements imply particular modes of studying that are important in each context. At Ace, the tables were arranged in rows, with seating to allow independent study or small group study. On the other hand, the tables and chairs at Tembusu were moved often, depending on the needs of the school. However, the layout in Figure 1, with tables arranged to make a large circle, resembling a large classroom discussion format was a regular feature. This arrangement is significant as it reflected the dominant use of the library as a large air-conditioned classroom space for students.

\section{Mapping Social Spaces}

The attention to the social is a deliberate attempt to observe overt behaviour that points to the spatial significance of particular organisations of space. It may confirm the how the physical layout and organization may encourage certain social behavior; on the other hand, one may also discover how space is used in ways contrary to official expectations. Shilling and Cousins (1990) viewing of the processes of colonization (with students using the library for unintended purposes) and regulation (by the librarian and other authority figures), of association and disassociation (where different groups of students can choose whether to occupy the library or vacate it at various times) within the library space highlight that the sense of space is both regulated and resisted. While those in authority may view the school library as a quiet study space or reading space, some students may resist this view of space, instead colonizing the educational space for meeting friends and chatting under the guise of 
A Socio-Spatial Study of School Libraries and Reading

work. In this section, I discuss my observations of the happenings in the library, focusing

particularly on the library as a reading space and as a study space. I juxtapose official

expectations with actual use to understand what the library actually meant to the students and

observe how the library was used in reality.

With regard to the use of the library as a study space, I saw many lessons being

conducted in the library at Tembusu but seldom observed students borrowing books or using

the library for research. The library was often used for some other purpose such as

conducting a test or meeting after school, making it unavailable to other students for reading

or studying. In the one week when I observed the use of the library after school, the library

was unavailable three out of five days because of meetings or class tests being conducted in

the library. In fact, the layout of the library with desks set in a large circle or in rows, as well

as the way it was actually used as extra classroom space, marked the library as additional

classroom space rather than a central space for independent knowledge acquisition and

learning about the acquisition of knowledge. The physical space implies that the library is not

so much a social space for interacting with and about books as it is a space for enforced work.

This perception of the library as a space for enforced work is reinforced by the fact that the

library is the place where students are sent to for detention.

In comparison, though students were also brought to the Ace library for work, the

nature of the work differed. While students were sent to the library to complete written work 
A Socio-Spatial Study of School Libraries and Reading

at times, including the completion of late work, I observed that teachers mostly brought their teachers to the library for research-based work such as Project Work, where students had to come up with their own research question for independent research. Samples of exemplary student work were kept in a back shelf in the library, and I observed the older students coming in to reference these works in preparation for their own research. Students also often had their own laptops, which they brought to the library to complete their work. The use of the library was modelled by some teachers who taught their students to use the resources in the library and online to find necessary information.

Mapping the social life of the library with a comparative lens brought up the fact that both libraries were often utilised by teachers for classroom work, but that the differing nature of classroom work set the tone for the students' perception of the utility value of the libraries. At Tembusu, students were often brought to the library to complete written work on the laptops that were kept away unless requested by a teacher for class work. In comparison, the perceived work of the library at Ace Independent included group work and research. The nature of classwork completed in the library affirmed for Ace students the need to independently search for information whereas there was a more functional approach towards knowledge with the focus on completion of written work.

In terms of reading spaces, there was little sofa space in both libraries for reading, and these spaces for often colonized for other purposes such as chatting, group discussion or 
A Socio-Spatial Study of School Libraries and Reading

independent work rather than reading or activities around reading (e.g., book discussions).

There was one sofa set beside the magazine shelf at Tembusu but the titles (such as National

Geographic, The Economist and Present Perfect, and education-related publication) were

pristine and seldom used. At Ace, the three armchair sets at the entrance of the library was

conducive to smaller groups chatting but as in Tembusu, the space was colonized for other

social purposes rather than reading. What differed was that there were a greater variety of

magazines including specialist magazines to do with topics such as photography or sports and

students tended to browse through these magazines more often, usually sitting at the nearby

tables and chairs. The greater variety of magazines was a draw for Ace students who may not

subscribe to these specialist magazines. Examining the affective responses of the students to

the school libraries and to reading and books help us to better understand how the social is

intimately tied to emotional association with particular places.

\section{Mapping Affective Spaces}

The affective responses of students to a space, derived from interviews with the students,

explained why the libraries were used as they were. Tembusu students, especially the low-

achieving and low-SES students, were not motivated to use the library because of their

perception of the library as being unattractive and lacking in social value. In my interviews

with 12 students, the word "boring" recurs at least six times, among other descriptions, when

asked to describe the Tembusu library. 
A Socio-Spatial Study of School Libraries and Reading

No one goes in and out of the library. There's nothing there. It's boring. (Edward, Tembusu Secondary, avid reader)

You only go to the library if you have detention! I never go to the library! (Cass, Tembusu Secondary, non-reader)

I don't really go the library. I prefer to go to the entertainment room if I have time. (Yi Han, non-reader)

Even Edward, an avid reader who visits the public library on a weekly basis, feels that his school library is unattractive, dead space. What was striking in the interviews was that students saw the amount of activity and the type of activity in a library as indication that it was a place worth going to. The fact that "no one goes in and out of the library" (a sentiment echoed a few times by other students) reinforced the students' perception that there was nothing attractive there. Moreover, the fact that the school library is used for detention contributes to students negative emotional responses. Already busy with schoolwork and cocurricular activities, students who could relax found the entertainment room located at a prime location near the canteen far more attractive than the library. Kate, another student, suggested that "a complete revamp, with bean bags and all" might draw her into the library, thus pointing to the affective as a necessary component for engagement (Smith \& Wilhelm, 2002). Students are drawn by the social life of a place to participate within the space.

Unlike the Tembusu students, the Ace Independent case study students liked their library, even though there were varying degrees of use. "Like" was a word often used to describe library. 
A Socio-Spatial Study of School Libraries and Reading

Sometimes, during recess, I sit at the sofa, and browse through the magazines, usually The Runner. I don't subscribe to that at home so it's useful that it's in school. (Sanjeev, Ace Independent, reader)

For example, Sanjeev, a school runner and prefect, did not need to go to the library to borrow fiction as his parents allow him to purchase books but he still saw the library as a space to relax and read The Runner, a magazine he does not subscribe to at home. Joel, a school librarian, talked about "hanging out" in the library after school and borrowing recommended books for his leisure reading. In fact, he had picked up Ayn Rand's The Fountainhead, a difficult philosophical read and one of his favourite books during library duty. Others such as Mark and Robert reported using the library less for reading as they had easy access to more books via bookstores or the public library, but talked about using it after school occasionally to do their work or for research. It was a place they independently and willingly stepped into when required or desired. The positive affective responses of Ace Independent students generally meant that they saw value in using the library and were motivated to use it.

The affective was recognised as an important element in the design and management of the Ace library, unlike Tembusu's more functional approach towards reading and acquisition of critical information literacy in the space of the library. Students' perception of the usefulness and accessibility of a place is in part dependent on their comfort level with space. Although there were attempts to cultivate a reading culture at Tembusu, the attempts were aimed to remediate the reader and failed to acknowledge that students may not buy into 
A Socio-Spatial Study of School Libraries and Reading

dominant strategies to improve themselves because of their own reader histories and non-

existent or negative relationships with books, reading and schooling (Hicks, 2002).

The different reader histories and relationships with books, reading and schooling are

particularly striking when comparing the practices and responses of the high-achieving

students from Ace Independent and the low-achieving students from Tembusu. For the high-

achieving students who fall into the category of "can read, do read freely", termed by Moss

(2007), they had acquired identities as readers and willingly engaged in texts, without the

need for prompting. They were independent, self-sufficient readers who could flexibly access

different kinds of texts for different purposes (Loh, 2013). On the other hand, for the low-

achieving students who “can’t yet, don't read" (Moss, 2007), more effort was required to

engage them in books and reading that would contribute to their academic learning. In

interviews with three low-achieving students from working-class backgrounds, they

confirmed that they only read books that interested them (Smith \& Wilhelm, 2002). As such,

out of the eight books allocated for reading as part of their reading programme, they only

completed Roald Dahl's Charlie and the Chocolate Factory because it was sufficiently

interesting for them to sustain reading. This suggests that educators need to account for the

affective in understanding how students relate to the school libraries and to the kinds of

learning associated with the school library. Listening to the voices of students and taking into 
A Socio-Spatial Study of School Libraries and Reading

account how students respond to library space is an important element for encouraging

library usage and uptake.

In the context of Tembusu, the dominant discourse driving reading practices is an emphasis on the functional-pragmatic value of reading, which distances low-achieving readers from the culture of reading. Instead, it might be more fruitful to re-conceptualise reading as a "media experience" (Fuller \& Sedo, 2013) where "entertainment and spectacle, social connection, intimacy, and, perhaps, a sense of belonging” (p. 249) can engage unmotivated readers. Re-visioning the library as a central space for making reading fun may serve to draw low-achieving readers into the library and encourage reading.

\section{Discussion and Conclusion}

While these two schools may not be representative of all schools in Singapore, the comparisons are "telling cases" (Mitchell, 1983) that provide insight into what differential resources indicate about the nature of learning in each context and how learning, in this case reading, is differently associated in the space of each school library. Clearly, in this case, Ace Independent is more richly resourced, whether in terms of the library space, the kinds of books available, or the staffing that contributes to making the library space work. The comparison has also demonstrated that it is not just absolute access but relative access that matters for students' learning. Questions that we can begin to ask in relation to rethinking our school library space can include the following: Do all students feel comfortable enough to 
A Socio-Spatial Study of School Libraries and Reading

enter the library? Who accesses the library? What kinds of learning are the students exposed to in the library? Are there mentors to provide students with guidance on how to access the library?

Furthermore, the study demonstrates how attending to the socio-spatial provides a framework for developing a detailed localized perspective of the responses to and usage of a school library. In this case, mapping the Tembusu library demonstrated that despite the school's commitment to improving students' reading and literacy skills, the library space was not effectively equipped or organized to encourage student to use it as a reading space and a space for information acquisition. Re-conceptualizing the library as social space highlights the kinds of activities that are privileged in the space provided. In Tembusu Secondary, because teachers tend to use the library for work, and because of the table arrangement, students tend to perceive the school library as enforced workspace rather than a reading space or a social space for engaging in book-related activities. In addition, the design and use of the library determined students' affective responses to the library, which in turn dictated whether they chose to use the library or not. Taking a socio-spatial approach provides us with a qualitative way to map out the effectiveness of individual school libraries, which are situated in their specific contexts of need and to rethink library space and programmes to cultivate the kinds of $21^{\text {st }}$ century learning desired. 
A Socio-Spatial Study of School Libraries and Reading

\section{Acknowledgements}

Parts of this paper was adapted from an original article: Loh, C. E. (2016) Levelling the reading gap: A socio-spatial study of school libraries and reading in Singapore. Literacy

50(1), 3-13. This work was funded by the English Language and Literature Academic Group

through the Office of Educational Research (OER), National Institute of Education (NIE), Nanyang Technological University, Singapore under Start-Up grant 8/13. Opinions stated and conclusions drawn do not represent the views of the Institute but are the author's own. 
A Socio-Spatial Study of School Libraries and Reading

\section{References}

Adkins, D., \& Brendler, B. M. (2015). Libraries and reading motivation: a review of the Programme for International Student Assessment reading results. International Federation of Library Associations and Institutions, 41(2), 129-139.

Barratt, L. (2010). Effective school libraries: evidence of impact on student achievement. The School Librarian, 58(3), 136-139.

de Certeau, M. (1984). The practice of everyday life (S. Randall, Trans.). California: University of California Press.

DelGuidice, M. (2015). The role of the library in fostering research skills. infotoday.com, $20-23$.

Dressman, M., \& Tettegah, S. (2006). Ordered by desire: school libraries in past and present times. In C. Kapitzke \& B. C. Bruce (Eds.), Libr@ries: changing information space and practice (pp. 37-48). Mahwah, New Jersey: Lawrence Erlbaum Associates, Publishers.

Fuller, D., \& Sedo, D. R. (2013). Reading beyond the book: the social practices of contemporary literary culture. NY: Routledge.

Gee, J. P. (1996). Social linguistics and literacies (2nd ed.). Oxford, Great Britain: RoutledgeFalmer. 
A Socio-Spatial Study of School Libraries and Reading

Gee, M. M. (1999). The roles and training needs of library support staff in Singapore school libraries. (Master of Science (Information Studies)), Nanyang Technological University, Singapore.

Gordon, C. A. (2010). The culture of inquiry in school libraries. School Libraries Worldwide, 16(1), 73-88.

Harvey, D. (2009). Social justice and the city. Georgia: University of Georgia Press.

Heath, S. B. (1986). Way with words: Language, life, and work in communities and classrooms. Cambridge: Cambridge University Press.

Hicks, D. (2002). Reading lives: Working-class children and literacy learning. New York: Teachers College Press.

Hochman, J. (2016). School library nostalgias. Curriculum Inquiry, 46(2), 132-147.

Jocson, K., \& Thorne-Wallington, E. (2013). Mapping literacy-rich environments: Geospatial perspectives on literacy and education. Teachers College Record, 115(6), 1-24.

Kapitzke, C. (2003). (In)formation literacy: a positivist epistemology and a politics of (out)formation. Educational Theory, 53(1), 37-53.

Kapitzke, C., \& Bruce, B. C. (2006). Libr@ries: changing information space and practice. Mahwah, New Jersey: Lawrence Erlbaum. 
A Socio-Spatial Study of School Libraries and Reading

Kirsch, I., de Jong, J., Lafontaine, D., McQueen, j., Mendelovits, J., \& Monseur, C. (2002).

Reading for change: performance and engagement across countries Paris:

Organisation for Economic Co-operation and Development.

Knapp, N. F. (2013). Cougar readers: Piloting a library-based intervention for struggling readers. School Libraries Worldwide, 19(1), 72-90.

Krashen, S. D. (2004). The power of reading: insights from research (2nd edition ed.). Portsmouth, NH: Heinemann.

Lance, K. C. (2002). What research tells us about the importance of school libraries. Knowledge Quest, 31(1), 17-22.

Lance, K. C., \& Hofshire, L. (2012). Change in school librarian staffing linked with change in CSAP reading performance, 2205-2011. Denver, CO: Denver Colorado State Library, Library Research Service.

Lareau, A. (2003). Unequal childhoods: class, race and family life. CA: University of California Press.

Leander, K. M., Phillips, N. C., \& Taylor, K. H. (2010). The changing social spaces of learning: mapping new mobilities. Review of Research in Education, 34, 329-393.

Lefebvre, H. (1991). The production of space (D. Nicholson-Smith, Trans.). Cambridge, MA: Blackwell. 
A Socio-Spatial Study of School Libraries and Reading

Loertscher, D. V., Preddy, L., \& Derry, B. (2013). Makerspaces in the School Library

Learning Commons and the uTEC Maker Model. Teacher Librarian, 41(2), 48-51.

Loh, C. E. (2013). Singaporean boys constructing global literate selves through their reading practices in and out of school. Anthropology and Education Quarterly, 44(1), 38-57.

Majid, S., Chaudhry, A., Foo, S., \& Logan, E. (2002). Developing 21st century School Media Resource Libraries for Singapore: An assessment and proposal from a library and information science education taskforce. Paper presented at the international Association of School Librarianship, Malaysia.

Makatche, K., \& Oberlin, J. U. (2011). Building a culture of reading. School Lirbary Monthly, 28, 12-14.

Mills, K. A., \& Comber, B. (2015). Socio-spatial approaches to literacy studies. In J. Roswell \& K. Pahl (Eds.), The Routledge handbook of literacy studies (pp. 91-103). New York: Routledge.

Mitchell, J. C. (1983). Case and situation analysis. Sociological Review, 31(2), 187-211.

Mokhtar, I. A. (2003). Evaluation of the collaborative relationship between teachers and school librarians in Singapore. (Master of Science (Information Studies)), Nanyang Technological University, Singapore. 
A Socio-Spatial Study of School Libraries and Reading

Mokhtar, I. A., \& Majid, S. (2005). Use of school libraries by teachers in Singapore schools. Library Review, 54(2), 108-118.

Moss, G. (2007). Literacy and gender: researching texts, contexts and readers. London: Routledge.

Nespor, J. (1997). Tangled up in school: Politics, space, bodies and signs in the educational process. New Jersey: Lawrence Erlbaum Association.

Neuman, S. B., \& Celano, D. (2012). Giving our children a fighting chance: poverty, literacy, and the development of information capital. NY: Teachers College Press.

Nichols, S. (2011). Young children's literacy in the activity space of the library: a geosemiotic investigation. Journal of Early Childhood Literacy, 11(2), 164-189.

Schmidt, S. J. (2015). A queer arrangement of school: using spatiality to understand inequity. Journal of Curriculum Studies, 47(2), 253-273.

Shilling, C., \& Cousins, F. (1990). Social use of the school library: the colonisation and regulation of educational space. British Journal of Sociology of Education, 11(4), 411-430.

Smith, M. W., \& Wilhelm, J. D. (2002). Reading don't fix no chevys: Literacy in the lives of young men. U.S.A.: Heinemann.

Soja, E. W. (2009). The city and spatial justice Spatial Justice. 
A Socio-Spatial Study of School Libraries and Reading

Solsken, J. W. (1993). Literacy, gender, and work in families and in schools. Norwood, New Jersey: Ablex Publishing Corporation.

Tan, C. N. (2003). School media resource libraries in Singapore: an assessment and potential developments. (Master of Science (Information Studies)), Nanyang Technological University, Singapore.

Todd, R. J., \& Kuhlthau, C. C. (2005). Student learning through Ohio school libraries, Part 1: how effective school libraries help students. School Libraries Worldwide, 11(11), 63-88.

Tsai, J. W. (2001). Refining roles and competencies of library coordinators in Singapore secondary schools. (Master of Science (Information Studies)), Nanyang Technological University, Singapore.

Warshauer, M. (2007). The paradoxical future of digital learning. Learning Inquiry, 1, 149.

Wejrowski, K., \& McRae, M. (2013). Developing a culture of readers through effective library planning. Knowledge Quest, 42(1), 38-43.

Yin, R. K. (2003). Case Study Research: Design \& Methods (3rd ed.). CA: Sage Publications. 